DOI: http://dx.doi.org/10.4314/star.v4i3.28

ISSN: 2226-7522(Print) and 2305-3372 (Online)

Science, Technology and Arts Research Journal

Sci. Technol. Arts Res. J., July-Sep 2015, 4(3): 184-186

Journal Homepage: http://www.starjournal.org/

Short Communication

\title{
Prevalence of Sputum Smear Positive Pulmonary Tuberculosis among the suspected visited patients in Selected Area of District Malakand, Pakistan
}

\author{
Tauseef Ahmad ${ }^{1 *}$, Haroon $^{2}$, Faisal Nouroz ${ }^{3}$, Amar Nath $^{4}$, Sabihuddin $^{5}$ and Eyasu Ejeta ${ }^{6}$ \\ ${ }^{1}$ Department of Microbiology, Hazara University, Mansehra-21300, Khyber Pakhtunkhwa, \\ Islamic Republic of Pakistan \\ ${ }^{2}$ Department of Zoology, Shaheed Benazir Bhutto University, Sheringal Dir Upper, \\ Khyber Pakhtunkhwa, Islamic Republic of Pakistan \\ ${ }^{3}$ Department of Bioinformatics, Hazara University, Mansehra-21300, Khyber Pakhtunkhwa, \\ Islamic Republic of Pakistan \\ ${ }^{4}$ Civil Government Hospital, Thana District Malakand, Khyber Pakhtunkhwa, Islamic Republic of Pakistan \\ ${ }^{5}$ District Tuberculosis Control Officer, Malakand, Khyber Pakhtunkhwa, Islamic Republic of Pakistan \\ ${ }^{6}$ Department of Medical Laboratory Sciences, Collage of Medical and Health Sciences, Wollega University, \\ P.O. Box: 395, Nekemte, Ethiopia

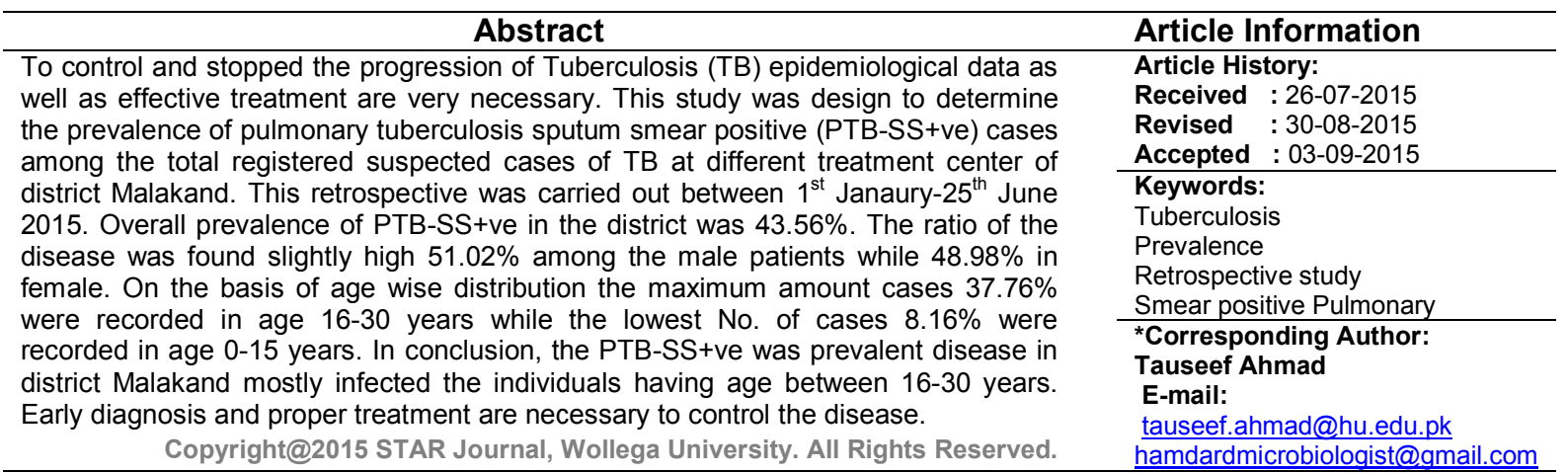

\section{INTRODUCTION}

Tuberculosis (TB) is second leading cause of death from an infectious disease worldwide, after the human immunodeficiency virus. It remains one of the world's deadliest communicable diseases and in 2013 alone, out of the estimated 9.0 million people developed TB disease, 1.5 million died (WHO, 2014). After the declaration in 1993 that tuberculosis was a global emergency, WHO launched the directly observed treatment, short-course (DOTS) strategy, which was successfully expanded as the principal tuberculosis control strategy, focusing primarily on detection and effective treatment of infectious cases (Raviglione and Uplekar, 2006). After a decade of implementation DOTS strategy, the new STOP TB Strategy and the Global Plan to Stop TB (2006-2015) were launched in 2006 to address important challenges that included the HIV-associated tuberculosis epidemic, the emergence of the MDR tuberculosis epidemic, weak health systems, and insufficient engagement with private healthcare providers and with communities (WHO, 2006). With these strategies, TB is slowly declining each year and it was estimated that 56 million patients were cured, 22 million lives were saved, and mortality rate was reduced with 45\% from 1990 to 2012 (WHO, 2014). However, given that most deaths from TB are preventable, the death toll from the disease is still unacceptably high and efforts to combat it must be accelerated and the WHO currently implementing the new strategies call Post 2015 strategies which have a vision to eliminate TB epidemic at 3035 (WHO, 2014).

Pakistan is among the top 14 TB and 4 MDR high TB burden countries in the world and the trend of the burden of the problem is did show any improvement from 1990 to 2013 (WHO, 2014). However, it has shown progressive improvement in treatment success rate $(>70 \%)$ among high burden countries. According to $\mathrm{WHO}$ estimation, the prevalence and incidences of TB is 342 (284-406) and 275 (205-357) in 2013 per 100,000 (WHO, 2014). 
Tauseef Ahmad et alo,

Identifying the prevalence of this public health problem will provide very important information in establishing feasible strategic plan in high TB countries like Pakistan. However, this information is lack in our study area. Therefore, this study was done to determine the Prevalence of sputum smear positive Pulmonary Tuberculosis in selected area of District Malakand in Pakistan.

\section{MATERIALS AND METHODS}

A six months (January-June 2015) hospital based retrospective study was conducted to find out the prevalence of sputum smear positive cases among the suspected visited patients. Study subject were all TB patients attending the treatment in January-June 2015. The purposively selected hospitals were District Head Quarter Hospital Batkhela, Tehsil Head Quarter Hospital Dargai and Civil Hospital Thana. The data were collected from the TB patients register. A total of 225 patients were
Sci. Technol. Arts Res. J., July-Sep 2015, 4(3): 184-186

registered and further process either for PTB or extrapulmonary TB. The patients have EPTB or sputum smear negative were excluded from the current study. The ethical approval was taken from the higher authority of the hospitals. The data was described using descriptive statically tool and presented using table.

\section{RESULTS}

In the present study a total of 225 suspected individuals was screen for TB infection (Table 1). The high No. of patients was registered in THQ Hospital Dargai followed by DHQ Hospital Batkhela and Civil Hospital Thana as shown in table 2. Of the total cases, 98 $(43.56 \%)$ was PTB-SS+ve with $50(51.02 \%)$ male and 48 $(48.98 \%)$ female as shown in table 2 . In area wise distribution the high prevalence of PTB-SS+ve was recorded in Thana followed by Batkhela and Dargai as describe in table 2 . The disease was prevailing in the age group between $16-30$ years (Table 3 ).

Table 1: Scio-demographic status of the registered TB patients

\begin{tabular}{clcc}
\hline \multicolumn{2}{c}{ Variable (N=225) } & Frequency & Percentage \\
\hline \multirow{2}{*}{ Sex } & Male & 108 & 48 \\
& Female & 117 & 52 \\
\hline \multirow{2}{*}{ Treatment } & THQ Hospital, Dargai & 121 & 53.78 \\
center name & DHQ Hospital, Batkhela & 81 & 36 \\
\cline { 2 - 4 } & Civil Hospital, Thana & 23 & 10.22 \\
\hline
\end{tabular}

Table 2: Gender wise distribution of Pulmonary TB sputum smear positive cases at different treatment center

\begin{tabular}{lcccc}
\hline $\begin{array}{c}\text { Treatment } \\
\text { center name }\end{array}$ & $\begin{array}{c}\text { Total } \\
\text { cases }\end{array}$ & $\begin{array}{c}\text { PTB-SS+ve } \\
\mathbf{( \% )}\end{array}$ & $\begin{array}{c}\text { Male } \\
\mathbf{( \% )}\end{array}$ & $\begin{array}{c}\text { Female } \\
(\mathbf{\%})\end{array}$ \\
\hline THQ Hospital, Dargai & 121 & $42(34.71)$ & $19(45.24)$ & $23(54.76)$ \\
DHQ Hospital, Batkhela & 81 & $41(50.62)$ & $23(56.1)$ & $18(43.9)$ \\
Civil Hospital, Thana & 23 & $15(65.22)$ & $8(53.33)$ & $7(46.67)$ \\
\hline Total & $\mathbf{2 2 5}$ & $\mathbf{9 8 ( 4 3 . 5 6 )}$ & $\mathbf{5 0 ( 5 1 . 0 2 )}$ & $\mathbf{4 8 ( 4 8 . 9 8 )}$ \\
\hline
\end{tabular}

Table 3: Overall age wise distribution of pulmonary TB sputum smear positive cases $(\mathrm{N}=98)$

\begin{tabular}{ccc}
\hline Age groups & Frequency & Percentage \\
\hline $0-15$ & 8 & 8.16 \\
$16-30$ & 37 & 37.76 \\
$31-45$ & 18 & 18.37 \\
$46-60$ & 16 & 16.33 \\
Above 60 & 19 & 19.39 \\
\hline
\end{tabular}

\section{DISCUSSION}

Every year millions of people were infected with TB. Majority of the TB cases are occurred in the developing countries. In our study the overall prevalence of PTBSS+ve was corroborate with other studies carried out by Saleem et al. (2013) at Kotli Azad Kashmir notified $44.73 \%$ cases of PTB-SS+ve.

In 2011, 270,394 cases of TB were reported from Pakistan (WHO, 2012). Overall results show that male is more infected rather than female. Our finding is similar with Saleem et al. (2013) reported high prevalence in male patients. Many region of the world have high male to female ratio i.e. Europe 2.16-1.00, South-east Asia 2.03-
1.00, Americas 1.49-1.00 and 1.35-1.00 in Africa (Dogar et al., 2012, Anderson and Menzies, 1995, Conde et al., 2000, Al-Zahrani et al., 2001)

There is large difference in smear positivity in the study institution which can partly reflect the tuberculosis prevalence difference in the community served at the study facilities. The presence of high prevalence of TB between 16-30 age groups could indicate the economic impact of TB in developing countries like the study area. These studies consist with other studies (Wood et al., 2010, Ejeta et al., 2012). This observed difference could be because of high prevalence of HIV in the age group in the area. 
Tauseef Ahmad et alo,

Apart from such important findings, this study is not without limitations. As common for secondary-data studies, some variables had not been recorded in registration book used in the study like socio-demographic data, anti HIV drug status, nutritional data, and presence of other chronic diseases which are potential factors for the development of TB diseases.

\section{CONCLUSIONS}

It was concluded that, smear positive pulmonary tuberculosis is prevalent in district Malakand. High ratio of cases was recorded in age between 16-30 years and female. Early diagnosis, proper treatment, awareness regarding the disease and good medical facility are necessary to decrease the burden of disease in district Malakand.

\section{Acknowledgements}

The authors are thankful to the patients and also extend their acknowledgement to treatment center of Batkhela, Dargai and Thana.

\section{Conflict of Interest}

Conflict of interest declared none

\section{REFERENCES}

Al-Zahrani, K., Al-Jahdli, H., Poirier L, Rene P, Menzies D. (2001) Yield of smear, culture and amplification tests from repeated sputum induction for the diagnosis of pulmonary tuberculosis. International Journal of Tuberculosis and Lung Disease 5: 855-860.

Anderson, N.I., Menzies, D. (1995) Comparison of sputum induction with fiber optic bronchoscopy in the diagnosis of tuberculosis. American Journal of Respiratory and Critical Care Medicine 33: 1570-1574.

Conde, M.B., Soares, S.L., Mello, F.C. (2000). Comparison of sputum induction with fiber optic bronchoscopy in the
Sci. Technol. Arts Res. J., July-Sep 2015, 4(3): 184-186

diagnosis of tuberculosis: experience at an acquired immune deficiency syndrome reference center in Rio de Janeiro, Brazil. American Journal of Respiratory and Critical Care Medicine 162: 2238-2240.

Dogar, O.F., Shah, S.K., Chughtai, A.A., Qadeer, E. (2012). Gender disparity in tuberculosis cases in eastern and western provinces of Pakistan. BMC Infectious Diseases 12: 244.

Ejeta, E., Legesse, M., Ameni, G. (2012). Preliminary Study on the Epidemiology of Tuberculosis in Nekemte and Its Surroundings -Western Ethiopia. Science, Technology and Arts Research Journal 1(1): 18-25.

Raviglione, M.C., Uplekar, M.W. (2006). WHO's new stop TB strategy. Lancet 367: 952-955.

Saleem, M., Ahmad, W., Jamshed, F., Sarwa, J., Nasreen, GU. (2013). Prevalence of tuberculosis in Kotli, Azad Kashmir. Journal of Ayub Medical College, Abbottabad 25(1-2): 175-178.

Wood, R., Liang, H., Wu, H., Middelkoop, K., Oni, T., Rangaka, X.M., Wilkinson, R.J., Bekker, L., Lawn, S.D. (2010) Changing prevalence of TB infection with increasing age in high TB burden townships in South Africa. International Journal of Tuberculosis and Lung Disease 14(4): 406-412

World Health Organization (WHO). (2006). Global tuberculosis control, surveillance, planning and financing, WHO Report, STOP TB Department WHO, Geneva, Switzerland, 2006.

World Health Organization (WHO). (2014). Tuberculosis epidemiology, prevention and control, tuberculosis economics, tuberculosis and multidrug-resistant and annual reports. WHO global tuberculosis report. WHO/HTM/TB/2014.08.

World Health Organization (WHO) (2012). Global Tuberculosis Report 2012. ISBN 9789241564502. WHO Geneva, Switzerland. 